6 Foster. D. L. and Fillingame. R. H. (1979) J. Biol. Chem. 254, 8230-82.36

7 Friedl, P., Friedl. C. and Schairer. H. U. (1979) Eur. J. Biochem. 100, 175-180

8 Okamoto, H., Sone, N., Hirata, H., Yoshida, M. and Kagawa, Y. (1979) J. Biol. Chem. 252 6125-6131

9 Sone, N., Yoshida, M., Hirata, H. and Kagawa, Y. (1978) Proc. Nall Acad. Sci. USA $75,4219-4223$

10 Negrin, R. S., Foster, D. C. and Fillingame R. H. (1980) J. Biol. Chem. 255, 5643-5648

11 Schneider, E. and Altendorf, K. (1980) FEBS Lett. 116, 173-176

12 Friedl. P. and Schairer, H. U. (1981) FEBS Lett. 128, 261-264

13 Schneider, E. and Altendorf, K. (1982) Eur. J Biochem. 126, 149-153

14 Miki, T., Hiraga, S., Nagata, T. and Yusa, T (1978) Proc. Natl Acad. Sci. USA 75 5099-5103

15 Foster, D. C.. Mosher, M. E.. Futai. M. and Fillingame, R. H. (1980) J. Biol. Chem. 255. 12037-12041

16 Foster. D. C. and Fillingame, R. H. (1982) J. Biol. Chem. 257. 20019-2015

17 Gay, N. J. and Walker, J. E. (1981) Nucleic
Acids Res. 9, 3919-3926

18 Kanazawa, H., Mabuchi, K., Kayano, T. Noumi, T., Sekiya, T. and Futai, M. (1981) Biochem. Biophys. Res. Commun. 103 613-620

19 Nielsen, J., Hansen, F. G., Hoppe, J.. Friedl, P. and v. Meyenburg, K. (1981) Mol. Gen. Genet. 184, 33-39

20 Steffens, K., Kiltz, H. H., Schneider, E. Schmid, R. and Altendorf, K. (1982) FEBS Lett. 142, 151-154

21 Bachmann, B. J. (1983) Microbiol. Rev. 47, 180-230

22 Gunsalus, R. P., Brusilow, W. S. and Simoni, R. D. (1982) Proc. Natl Acad. Sci. USA 79 320-324

23 Hoppe, J., Friedl, P., Schairer, H. U., Sebald, W., Jørgensen, B. and v. Meyenburg, K (1983) EMBO J. 2. 105-110

24 Hoppe. J., Montecucco. C. and Friedl. P (1983) J. Biol. Chem. 258, 2882-2885

25 Schairer, H. U., Hoppe, J., Sebald, W. and Friedl, P. (1982) Bioscience Rep. 2, 631-639

26 Steffens, K., Schneider, E., Herkenhoff, B., Schmid, R. and Altendorf, K. Eur. J. Biochem. (in press)

27 Sebald. W. and Hoppe, J. (1981) Curr. Top
Bioenerg. 12, 1-64

28 Cattell, K. J., Lindop, C. R., Knight, I. G. and Beechey, R. B. (1971) Biochem. J. 125 169-177

29 Wachter, E., Schmid, R., Deckers, G. and Altendorf, K. (1980) FEBS Lett. 113, 265-270

30 Hoppe, J., Schairer, H. U., Friedl, P. and Sebald. W. (1982) FEBS Lett. 145, 21-24

31 Friedl, P., Hoppe, J., Gunsalus, R. P. Michelsen, O., v. Meyenburg, K. and Schairer, H. U. (1983) EMBO J. 2, 99. 103

32 Deckers, G., Schmid, R., Kiltz, H. H. and Altendorf, K. (1982) EBEC Reports 2, 77-78

33 Hoppe, J. and Brunner, J. (1983) Eur. J. Cell. Biol., Suppl. 2, 16

34 Walker, J. E., Saraste, M. and Gay, N. J. (1982) Nature 298, 867-869

35 Noumi, T. and Kanazawa, H. (1983) Biochem Biophys. Res. Commun. 111, 143-149

36 Fillingame, R. H., Mosher, M. E., Negrin R. S. and Peters, L. K. (1983) J. Biol. Chem. $258,604-609$

37 Cox, G. B., Downie, J. A., Langman, L.. Senior, A. E., Ash, G., Fayle, D. R. H. and Gibson, F. (1981) J. Bacteriol. 148, 30-42

38 Senior. A. E. (1983) Biochim. Biophys. Acta $726,81-95$

\title{
Renewed interest in the polyphosphoinositides
}

\section{Stephen K. Fisher, Lucio A. A. Van Rooijen and Bernard W. Agranoff}

The significance of the enhanced cellular phosphatidate and phosphatidylinositol turnover which occurs in response to specific extracellular messengers has been the subject of much interest and speculation. Until recently, much less attention has been paid to the presence of two quantitatively minor phosphorylated derivatives of phosphatidylinositol, known collectively as the polyphosphoinositides. These lipids have an extremely rapid ${ }^{32} P$ turnover rate and are presumed to be localized predominantly in the plasma membranes. Their turnover now appears to be linked with that of phosphatidate and phosphatidylinositol, and is discussed here in relation to the consequences of ligand-receptor interactions.

\section{Polyphosphoinositides as cell membrane components}

Phosphatidylinositol (Phl), as well as two phosphorylated derivatives, phosphatidylinositol 4-phosphate (PhIP) and phosphatidylinositol 4,5-bisphosphate $\left(\mathrm{PhIP}_{2}\right)$, are found in eukaryotic membranes (see Fig. 1). Because of the highly polar nature of these lipids, their quantitative extraction from tissues usually requires conditions of acidity or high ionic strength, and special thin layer chromatographic procedures are

The authors are at the Neuroscience Laboratory Building, University of Michigan, Ann Arbor, MI 48109, USA. The present address of S. K. Fisher is: Department of CNS Research. Medical Research Division of American Cyanamid Company, Lederle Laboratories, Pearl River, $N Y$ 10965, USA needed for their separation. These two factors may explain much of the past neglect of ligand-stimulated turnover of the polyphosphoinositides. An even more important factor is their rapid resynthesis, such that lipid breakdown can go unnoticed if it is not measured within seconds of ligand addition.

\section{Subcellular distribution and metabolism}

$\mathrm{PhIP}$ and $\mathrm{PhIP}_{2}$ are synthesized from endogenous PhI via sequential phosphorylation by ATP at the D-4 and D-5 positions of the myo-inositol moiety, under the action of specific kinases. In turn, phosphomonoesterases can dephosphorylate $\mathrm{PhIP}_{2}$ to $\mathrm{PhIP}$ and PhIP to PhI. The combined effects of the kinases and monoesterases result in the rapid equilibration of radioactivity in the gamma position of ATP with that of the inositide monoester functions. Alternatively, the entire headgroup of the polyphosphoinositides can be removed via phosphodiesteratic cleavage of the phospholipase $\mathrm{C}$ variety to yield the apolar product, diacylglycerol (DAG), together with inositol bis- or trisphosphate from PhIP or $\mathrm{PhIP}_{2}$, respectively. Available information from subcellular fractionation studies suggests that most of the relevant enzymes of polyphosphoinositide metabolism are present in both the plasma membrane and in the cytosol $^{2}$. The ability to form labeled $\mathrm{PhIP}_{2}$ from endogenous PhIP and $\left[\gamma^{32} \mathrm{P}\right]$ ATP is a convenient measure of PhIP kinase, and has been demonstrated in purified plasma membrane preparations, as well as in plasma membrane-enriched tissues, e.g. brain, kidney, polymorphonuclear leukocytes and erythyrocytes $^{2}$. However, PhI kinase and/or PhIP kinase activity has also been documented in adrenal chromaffin granules, mitochondria, lysosomes, Golgi preparations and the nuclear envelope. $\mathrm{PhI}$ and $\mathrm{PhIP}$ kinases are $\mathrm{Mg}^{2+}$ dependent, while the effects of $\mathrm{Mg}^{2+}$ and $\mathrm{Ca}^{2+}$ on the lipid phosphomonoesterase activities appear to vary with the tissue source of the enzyme. There is general agreement that $\mathrm{Ca}^{2+}$ ions at millimolar concentrations selectively activate the phosphodiesterase(s), although the optimal concentration appears to depend upon the assay conditions employed. The enzymatic potential for degradation of the polyphosphoinositides 
in brain exceeds that of synthesis by one or two orders of magnitude, the most active being an apparent 'phospholipase C' phosphodiesteratic activity. Other possible pathways for polyphosphoinositide degradation, for example via phospholipase $\mathrm{D}$ or $\mathrm{A}_{2}$ activity, are minor. It thus appears that the breakdown of polyphosphoinositides via a type $\mathrm{C}$ phosphodiesteratic cleavage is likely to be of most physiological significance.

\section{Receptors coupled to polyphosphoinosi- tide turnover}

The Hokins first demonstrated that activation of certain receptors (e.g. muscarinic cholinergic or $\alpha_{1}$-adrenergic) resulted in increased incorporation of added ${ }^{32} \mathrm{P}_{\mathrm{i}}$ into phosphatidate ( $\left.\mathrm{PhA}\right)$ and $\mathrm{PhI}$. It was subsequently reported that there was a net loss of PhI upon stimulation with the accumulation of an approximately equivalent amount of $\mathrm{PhA}^{3}$. This was thought to arise from an initial phosphodiesteratic breakdown of PhI, liberating DAG which was in turn

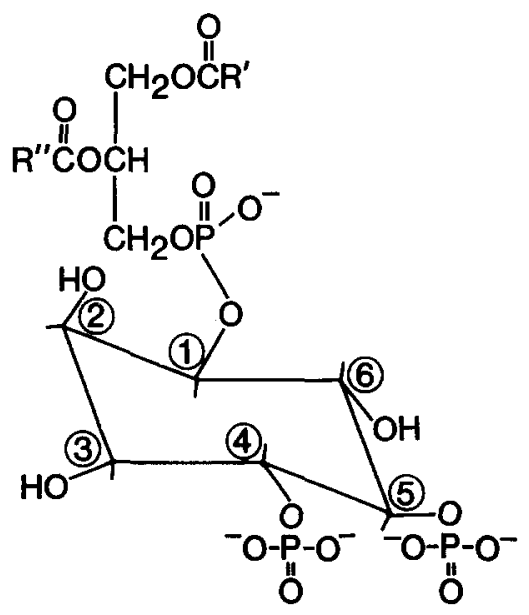

Fig. 1. The structure of phosphatidylinositol 4,5bisphosphate $\left(\mathrm{PhIP}_{2}\right)$. Phosphatidylinositol (PhI) is phosphodiesterified at D-1 of myo-inositol, and has no phosphomonoester substituents, while phosphatidylinositol 4-phosphate $(P h I P)$ is phosphorylated only at the D-4 position. PhI, PhIP and $\mathrm{PhIP}_{2}$ are also commonly abbreviated as MPI, DPI and TPI (for mono-, di- and triphosphoinositide). The IUB-IUPAC recommended abbreviations are, respectively, Ptdlns, PtdIns4P and PtdIns $(4,5) P_{2}$. These latter abbreviations, however, have been the subject of some confusion related to their correct structural assignments ${ }^{I}$. In each of the three inositides, the phosphodiesteratically-linked 1,2-diacyl-sn-glycero-3-phosphate is enriched in the 1-stearoyl, 2-arachidonoyl species. The possibility that the inositol lipids serve as a reservoir of arachidonate for prostanoid synthesis has been proposed, although it is not yet clear which inositide or inositide-related lipid is the donor. In this paper, myo-inositol D-1-phosphate, myo-inositol-D-1,4-bisphosphate and myo-inositolD-1,4,5-trisphosphate are referred to as $I P_{1}, I P_{2}$ and $\mathrm{IP}_{3}$

TABLE I. Receptors coupled to polyphosphoinositide turnover in target tissues

\begin{tabular}{lll}
\hline Tissue & Receptor & Refs \\
\hline $\begin{array}{l}\text { Iris smooth muscle } \\
\text { Hepatocytes }\end{array}$ & $\begin{array}{l}\text { Muscarinic cholinergic, } \alpha_{1} \text {-adrenergic } \\
\text { Parotid gland }\end{array}$ & $\begin{array}{l}\text { Vasopressin, angiotensin } \\
\text { Muscarinic cholinergic, } \alpha_{1} \text {-adrenergic, }\end{array}$ \\
substance P & 7,8 \\
Platelets & Thrombin, ADP, platelet activating factor & $11-14$ \\
Brain (nerve ending & Muscarinic cholinergic, ACTH & $10,15,16$ \\
$\quad$ preparations or slices) & & 17 \\
Avian salt gland & Muscarinic cholinergic & 10 \\
Adrenal gland & 5-HT, & 18 \\
Pancreas & ACTH & 19 \\
\hline
\end{tabular}

rapidly rephosphorylated in the presence of $\left[{ }^{32} \mathrm{P}\right] \mathrm{ATP}$ to yield $\left[{ }^{32} \mathrm{P}\right] \mathrm{PhA}$. The $\mathrm{PhA}$ was then proposed to be converted to $\mathrm{PhI}$ via (CDP-DAG)*, completing a 'phosphatidate-phosphatidylinositol cycle' (Fig. 2). The vast number of studies on stimulated incorporation of ${ }^{32} \mathrm{P}_{\mathrm{i}}$ into $\mathrm{PhA}$ and $\mathrm{PhI}$ or of $\left[{ }^{3} \mathrm{H}\right]$ inositol into $\mathrm{PhI}$ are thus several steps away from the presumed site of receptorligand action, i.e. phosphodiesteratic cleavage. In an early study, Durell et $a l .{ }^{4}$ noted a possible increased production of inositol bisphosphate, under conditions of stimulation of brain homogenate with acetylcholine. Despite this observation, and the known metabolic interrelationships between the inositol lipids, a direct effect of receptor activation on $\mathrm{PhIP}$ and $\mathrm{PhIP}_{2}$ turnover was not proposed or examined further until 1977, when Abdel-Latif and colleagues demonstrated that exposure of the iris smooth muscle to acetylcholine resulted in increased breakdown of ${ }^{32} \mathrm{P}$-prelabeled $\mathrm{PhIP}_{2}$ (Ref. 5). These experiments, as well as a number of other indirect indications, led to intensified efforts to identify changes in polyphosphoinositides associated with receptor activation. There are by now numerous documented examples of receptor-ligand interaction linked to polyphosphoinositide turnover (Table I). In most instances, this has been measured by loss of polyphosphoinositide radioactivity from $\left[{ }^{3} \mathrm{H}\right]$ inositol or ${ }^{32} \mathrm{P}$-prelabeled cells. Such studies indicate that radiolabeled $\mathrm{PhIP}_{2}$, and in some instances PhIP as well, is rapidly diminished following addition of a specific ligand. For example, $20 \%$ or more of label in $\mathrm{PhIP}_{2}$ is lost within 5-30 s of exposure of platelets to thrombin, of hepatocytes to vasopressin, or of parotid gland slices to methacholine. There is evidence in the iris smooth muscle, in platelets, and in blowfly salivary gland for the simultaneous release of inositol trisphosphate, a result consistent with

${ }^{*} \mathrm{CDP}-\mathrm{DAG}=$ cytidine diphosphadiacyl glycerol. the phosphodiesteratic cleavage of $\mathrm{PhIP}_{2}$ following receptor activation. The rapidity with which the lipid breaks down following ligand addition suggests that the cleavage of $\mathrm{PhIP}_{2}$ rather than of PhI constitutes the initial event following receptor activation and that the disappearance of $\mathrm{PhI}$ is a secondary response which reflects the process of replenishment of the depleted polyphosphoinositide pool.

Of potential relevance are recent studies with isolated synaptic membranes. Gispen and colleagues have shown that the addition of adrenocorticotropin (ACTH) to these preparations results in an increase in polyphosphoinositide labeling ${ }^{15}$. The effects are interpreted to reflect increased phosphorylation of $\mathrm{PhIP}$ to $\mathrm{PhIP}_{2}$. The presumed mechanism is inhibition by ACTH of the phosphorylation of a membrane protein of about $M_{\mathrm{r}} 48000$ ('B50') whose phosphorylated form inhibits PhIP kinase. The B50 kinase is thought to be similar or perhaps identical to protein kinase $\mathrm{C}$, found commonly in the cytosol of a number of tissues, particularly brain. While the protein kinase $C$ is isolated from the cytosol and the B50 kinase is membrane-bound, free and bound forms of protein kinase $\mathrm{C}$ have been found in cultured cells, and their ratio is reportedly altered by the presence of phorbol esters $^{20}$. ACTH administration, both in vivo and in vitro, results in a rapid increase in the chemical amounts of both PhIP and $\mathrm{PhIP}_{2}$ in the adrenal, with a time course similar to that reported for corticosterone production ${ }^{18}$. Direct additions of $\mathrm{PhIP}$ and $\mathrm{PhIP}_{2}$ to adrenal mitochondria are reported to increase the rate of side chain cleavage of cholesterol to form pregnenolone, a result suggesting that the polyphosphoinositides play a significant role in steroidogenesis.

\section{Calcium and the polyphosphoinositides}

Since many receptor-ligand actions that affect polyphosphoinositide turn- 


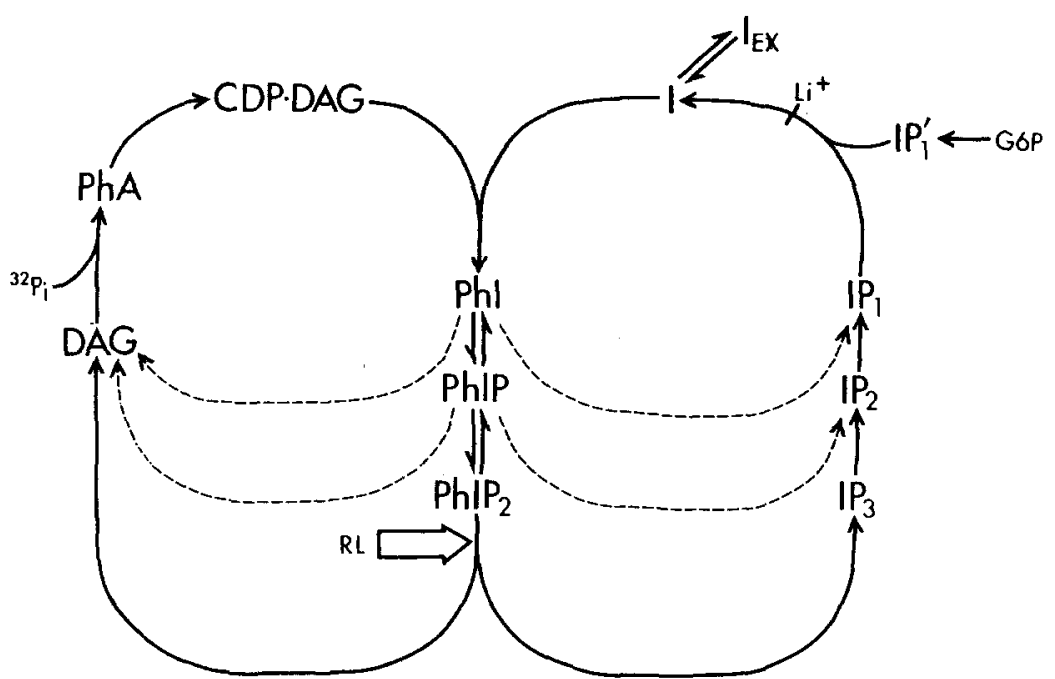

Fig. 2. Cyclic turnover of inositol lipids. The originally proposed cycle (upper left) of $P h l \rightarrow D A G \rightarrow>$ $P h A \rightarrow C D P-D A G \rightarrow P h l$ is now extended to include the polyphosphoinositides. While phosphodiesteratic cleavage of PhIP is indicated, there is better evidence for stimulated $P h I P_{2}$ breakdown following receptor-ligand $(R L)$ activation. The cycle on the right demonstrates the sequential breakdown of $I P_{3}$ to inasitol. The breakdown of $\mathrm{IP}_{I}$ is blocked by $\mathrm{Li}^{+}$. Cellular inositol is supplied exogenously $\left(I_{e x}\right)$ or produced by degradation of $L$-myo-inositol phosphate (IP') formed via cyclization of glucose-6-phosphate (G6P).

over exert their physiological effects by increasing intracellular $\mathrm{Ca}^{2+}$, it is not surprising that a direct role for $\mathrm{Ca}^{2+}$ in the metabolism. of these phospholipids has also been proposed. Central to this issue is the question of whether the increased lipid turnover either (1) is the consequence of an increase in cytosolic $\mathrm{Ca}^{2+},(2)$ mediates the increase in $\mathrm{Ca}^{2+}$ permeability, or (3) parallels, but is independent of, $\mathrm{Ca}^{2+}$ mobilization. In support of the first possibility is the finding that the muscarinic cholinergic or $\alpha_{1}$-adrenergic stimulated breakdown of $\mathrm{PhIP}_{2}$ in iris smooth muscle requires added $\mathrm{Ca}^{2+}$, is abolished in the presence of EGTA or inhibuors of $\mathrm{Ca}^{2+}$ translocation, $\mathrm{a}^{-} \mathrm{i}$ can be induced by the addition of $\mathrm{Ca}^{2+}$ ionophores ${ }^{6}$. In hepatocytes, vasopressin stimulation of $\mathrm{PhIP}_{2}$ breakdown is abolished in the presence of EGTA ${ }^{7}$. Furthermore, the introduction of $\mathrm{Ca}^{2+}$ into a nerve ending preparation with the divalent cation ionophore A23187 stimulates the breakdown of PhIP and $\mathrm{PhIP}_{2}$, under conditions in which inositol phosphates accumulate $^{21}$. On the other hand, the stimulated breakdown of $\mathrm{PhIP}_{2}$ in the parotid gland, platelet and pancreas appears insensitive to $\mathrm{Ca}^{2+}$ depletion, or is at least less so than the attendant physiological responses. This latter result supports the second possibility, namely that $\mathrm{PhIP}_{2}$ breakdown reflects a molecular mechanism whereby cells gate $\mathrm{Ca}^{2+}$, so that increased turnover of $\mathrm{PhIP}_{2}$ is not regulated by the increase in intracellular $\mathrm{Ca}^{2+}$. An alternative explanation is that these cells are not easily depleted of $\mathrm{Ca}^{2+}$ in the presence of extracellular EGTA. The various results, taken together, are compatible with the interpretation that polyphosphoinositide turnover is $\mathrm{Ca}^{2+}$-dependent, but may not be $\mathrm{Ca}^{2+}$-regulated.

Because of the known high affinity of polyphosphoinositides for binding $\mathrm{Ca}^{2+}$ ions, their plasma membrane localization and potential for rapid degradation upon receptor activation, these lipids have been considered as a possible reservoir of cell $\mathrm{Ca}^{2+}$. It has been demonstrated that the $\mathrm{Ca}^{2+}$-binding activity of erythrocytes increases directly with the state of inositide phosphorylation ${ }^{22}$. Similarly, phosphorylation of renal brush border membrane vesicles results in stimulation of $\mathrm{Ca}^{2+}$ intake, with increased phosphoinositide and PhA content $^{23}$. It is less certain, however, that the chemical amounts of $\mathrm{Ca}^{2+}$ bound to polyphosphoinositides suffice to account for the increase in cytosolic $\mathrm{Ca}^{2+}$ resulting from receptor activation. Calculations of amounts of $\mathrm{Ca}^{2+}$ released from $\mathrm{PhIP}_{2}$ in hormone-stimulated hepatocytes indicate that only a small fraction of the measured $\mathrm{Ca}^{2+}$ released from these cells could be derived from the polyphosphoinositide pool. In the case of platelets, the calculated amounts of $\mathrm{Ca}^{2+}$ released from $\mathrm{PhIP}_{2}$ following ADP addition could, however, account for an increase in intracellular $\mathrm{Ca}^{2+}$ by $10 \mu \mathrm{M}^{13}$. These observations must be tempered by considerations of conditions in vivo. For example, these various calculations assume that $\mathrm{Ca}^{2+}$ is the sole cation present. Although cytosolic $\mathrm{Mg}^{2+}$ is in fact present at greater concentration than $\mathrm{Ca}^{2+}$ and binds to the polyphosphoinositides with similar affinity, $\mathrm{Mg}^{2+}$ or $\mathrm{Ca}^{2+}$ salts of the polyphosphoinositides probably have different affinities for the enzymes for which they are substrates.

It is alternatively possible that products of phosphoinositide turnover trigger the rise in cell $\mathrm{Ca}^{2+}$. For example, phosphatidate has been shown to have $\mathrm{Ca}^{2+}$ ionophore activity, as have arachidonate metabolites. Another candidate is $\mathrm{IP}_{3}$, a product of $\mathrm{PhIP}_{2}$ degradation. Preliminary reports indicate that $\mathrm{IP}_{3}$ can increase $\mathrm{Ca}^{2+}$ efflux from cells under specified conditions ${ }^{24}$. In platelets, the physiological response resulting from a rise in intracellular $\mathrm{Ca}^{2+}$ can be mimicked by accumulation of DAG, this effect being mediated through activation of protein kinase $C$ (Ref. 25). Thus, the production of both DAG and $\mathrm{IP}_{3}$ may be necessary for expression of a full response. In fact, experimentallyinduced increases in intracellular $\mathrm{Ca}^{2+}$ and DAG elicit synergistic rather than additive cell responses in the platelet ${ }^{26}$.

\section{Inositide turnover in the nervous system}

While much of our present knowledge of the polyphosphoinositides has been obtained with non-neural preparations, it is likely that the role of these lipids in the central nervous system will come under increasing scrutiny. Brain contains high concentrations of polyphosphoinositides localized to two distinct pools: a metabolically stable pool associated with myelin and a more labile pool present in neuronal or glial plasma membranes ${ }^{27}$. Nerve ending preparations support a muscarinic cholinergic stimulation of PhA and Phl labeling, which has been localized post-synaptically $^{28}$. Membranes from nerve ending preparations contain $\mathrm{Ca}^{2+}$-activated phosphodiesterase, capable of the rapid degradation of endogenous $\mathrm{PhIP}_{2}$ and $\mathrm{PhIP}^{29}$. Although there is evidence for a neurotransmitter-linked effect on PhIP and $\mathrm{PhIP}_{2}$ turnover, direct stimulation of inositol lipid breakdown in the CNS and corresponding release of inositol phosphates is difficult to demonstrate. However, the observation by Allison $e t$ al. ${ }^{30}$ that lithium administration to rats results in an intracerebral accumulation of $\mathrm{IP}_{1}$, has been successfully exploited in vitro. A stimulated release of $I P_{1}$ can be detected following the addition of a number of neurohormones to brain slices incubated in the presence of $\mathrm{Li}^{+}$(Ref. 
31). This effect of $\mathrm{Li}^{+}$is believed to be due to an inhibition of the phosphatase that degrades $\mathrm{IP}_{1}$ (Fig. 2). The increase in $\mathrm{IP}_{1}$ could result from the phosphodiesteratic cleavage of $\mathrm{PhI}$, but recent evidence favors an initial release of $\mathrm{IP}_{3}$ (Ref. 10), followed by degradation to $\mathrm{IP}_{1}$ by phosphatases. Whether this effect of $\mathrm{Li}^{+}$can be related to its known psychotherapeutic effects remains an open question. However, its use as an experimental tool can be expected to provide much new information, both in the identification of new neurotransmitter systems which exert their effects through inositol lipid turnover and in the elucidation of the role of polyphosphoinositides in cell-cell communication in the brain.

\section{References}

1 Agranoff, B. W. (1978) Trends Biochem. Sci. 3, N283-285

2 Michell, R. H. (1975) Biochim. Biophys. Acta 415, 81-147

3 Hokin-Neaverson, M. R. (1974) Biochem. Biophys. Res. Commun. 58, 763-768

4 Durell, J., Sodd, M. A., Friedel, R. O. (1968) Life Sci. 7, 363-368

5 Abdel-Latif, A. A., Akhtar, R. A. and
Hawthorne, J. N. (1977) Biochem. J. 162, 61-73

6 Abdel-Latif, A. A. (1983) in Handbook of Neurochemistry, 2nd Ed., Vol. 3 (Lajtha, A., ed.), pp. 91-131, Plenum Press, New York

7 Rhodes, D., Prpic, V., Exton, J. H. and Blackmore, P. F. (1983) J. Biol. Chem. 258, 2770-2773

8 Creba, J. A., Downes, C. P., Hawkins, P. T., Brewster, G., Michell, R. H. and Kirk, C. J. (1983) Biochem. J. 212, 733-747

9 Weiss, S. J., McKinney, J. S. and Putney, J. W., Jr (1982) Biochem. J. 206, 555-560

10 Berridge, M. J., Dawson, R. M. C., Downes, C. P., Heslop, J. P. and Irvine, R. F. (1983) Biochem. J. 212, 473-482

11 Agranoff, B. W., Murthy, P. and Seguin, E. B. (1983) J. Biol. Chem. 258, 2076-2078

12 Billah, M. M. and Lapetina, E. G. (1982) Biochem. Biophys. Res. Commun. 109, 217-222

13 Vickers, J. D., Kinlough-Rathbone, R. L. and Mustard, J. F. (1982) Blood 60, 1247-1249

14 Billah, M. M. and Lapetina, E. G. (1983) Proc. Natl Acad. Sci. 80, 965-968

15 Jolles, J., Zwiers, H., Dekker, A., Wirtz, K. W. A. and Gispen, W. H. (1981) Biochem. J. 194, 283-291

16 Fother, S. K. and Agranoff, B. W. (1981) J. Neurochem. 37, 968-977

17 Fisher, S. K., Hootman, S. R., Heacock, A. M., Ernst, S. A. and Agranoff, B. W (1983) FEBS Lett. 155, 43-46
18 Farese, R. V., Sabir, A. M., Vandor, S. L. and Larson, R. E. (1980) J. Biol. Chem. 255, 5728-5734

19 Putney, J. W., Burgess, G. M., Halenda, S. P., McKinney, J. S. and Rubin, R. P. (1983) Biochem. J. 212, 483-488

$20 \mathrm{Kraft}$. A. S. and Anderson, W. B. (1983) Nature 301, 621-623

21 Griffin, H. D. and Hawthorne, J. N. (1978) Biochem. J. 176, 541-552

22 Buckley, J. T. and Hawthorne, J. N. (1972) J. Biol. Chem. 247, 7218-7223

23 Hruska, K. A., Mills, S. C., Khalifa, S. and Hammerman, M. R. (1983) J. Biol. Chem. $258,2501-2507$

24 Streb, H., Irvine, R. F., Berridge, M. J. and Schulz, I. Nature 306, 67-69

25 Nishizuka, Y. (1983) Trends Biochem. Sci. 8, 13-16

26 Michell, R. H. (1983) Trends Biochem. Sci. 8, 263-265

27 Eichberg, J. and Hauser, G. (1967) Biochim. Biophys. Acta 144, 415-422

28 Agranoff, B. W. (1983) Life Sci. 32, 2047-2054

29 Van Rooijen, L. A. A., Seguin, E. B. and Agranoff, B. W. (1983) Biochem. Biophys. Res. Commun. 112, 919-926

30 Allison, J. H., Blisner, M. E., Holland, W. H., Hipps, P. P. and Sherman, W. R. (1976) Biochem. Biophys. Res. Commun. 71, $664-670$

31 Berridge, M. J., Downes, C. P. and Hanley, M. R. (1982) Biochem. J. 206, 587-595

\section{Effects of progesterone: synergy and antagonism with oestrogens}

\author{
Jan Mester and Etienne-Emile Baulieu
}

Progesterone and oestradiol display a complex pattern of actions on many biochemical parameters in their target cells. The synergy and antagonism of the two hormones appear to be related to the control they exert on the concentration and subcellular distribution of their respective receptors.

The functions of the tissues implicated directly or indirectly in reproduction processes are under the control of the sex steroid hormones. In the female, the hypothalamic and pituitary hormones regulate the secretion of oestrogens and progesterone by the ovary; the feedback by these steroids controls the pattern of sexual behaviour and reproductive capacity

For the necessary fine tuning of hormonally regulated processes in the target tissues, the organism must ensure that a response to the same stimulus at different times can be amplified or attenuated according to need. Progesterone, in

Jan Mester and Etienne-Emile Baulieu are at the Lab. Hormones, Inserm U33, 94270 Bicêtre, France. addition to the effects it exerts on the differentiation and function of some tissues, seems to play the role of this 'second handle' for the oestrogen-dependent processes in many organs related to reproductive function in the female. Its antagonism of oestrogen has long been known ${ }^{1}$, and more recent evidence demonstrates that the same hormone can potentiate, amplify or sometimes mimic oestrogenic activity. The amplitude of the response of the tissue to progesterone depends in turn on the preceding oestrogen 'priming' of the tissue with resulting synthesis and accumulation of progesterone receptors. In this review we summarize and analyse progesterone and their possible mechanisms. these apparently contradictory roles of
Effect of progesterone alone

Although the name progesterone indicates that the hormone is necessary for the maintenance of gestation, it is also an important factor in the regulation of reproductive functions in lower animals such as birds and amphibians. All the tissues related to female reproduction that have been studied possess intracellular proteins ('receptors') with high affinity for progesterone and related molecules. The specificity of binding to progesterone receptors correlates well with the biological activity of the respective compound, supporting the hypothesis that the receptors are involved in the mediation of hormone action ${ }^{2}$.

In the absence of hormone, virtually all progesterone receptors are recovered in the high-speed supernatant fraction ('cytosol') of tissue homogenates, and display certain properties characteristic of what has been defined as the 'native' (non-activated) form. These include, in particular, low binding to isolated nuclei and to certain natural (DNA) or synthetic (phosphocellulose; ATP-agarose) polyanions, as well as a large size indicated by a sedimentation coefficient of $\sim 8 \mathrm{~S}$ in density gradients. The actual progestin-binding sites are situated on two subunits. A (mol. wt $\sim 79000$ ) and $\mathrm{B}(\mathrm{mol}$. wt $\sim 110000)$, which have been 